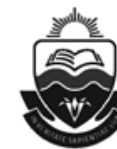

\title{
P.J. NAUDÉ
}

\section{WHY IS A MULTIPLICITY OF CONFESSIONS PARTICULAR TO THE REFORMED TRADITION?}

\section{ABSTRACT}

This article commences with the observation - drawn from a number of standard collections - that a multiplicity of confessions is a particular trait of the Reformed tradition. An explanation for this is then sought with reference to the very conception of theology in the Reformed tradition (Willie Jonker); the spiritual power of the church to declare doctrine (John Calvin), and the relative authority of the confessions themselves (Karl Barth). It is concluded that new confessions will continue to emerge in this tradition as the gospel is proclaimed or put under threat in possible new circumstances in future.

\section{INTRODUCTION}

The significance of the confession in the Reformed church consists in its essential non-significance, its obvious relativity, humanity, multiplicity, mutability, and transitoriness ... Reformed confession is confession of the truth of Scripture; as long as and to the extent that it is this, it has not ceased to exist (Barth 2002:38, 40). ${ }^{1}$

Putting forward a confessional statement, the Bernese synod of 1532 provides a classical example of the Reformed view on confessions:

If something would be brought forward to us from our pastors or others, which leads us closer to Christ, and which is, according to the Word of God, more conducive to general friendship and

1 Karl Barth in The theology of the Reformed confessions from lectures held in 1923.

Prof. Piet Naudé, University of Stellenbosch Business School, South Africa. E-mail: piet.naude@usb.ac.za 
Christian love than the opinion recorded now, we are happy to accept it and do not want to block the way of the Holy Spirit (Locher in Busch 2003:23). ${ }^{2}$

In the introduction to his vast collection of the major theological affirmation of the Christian churches, John Leith (1973:1) makes the general observation that "Christianity has always been a creedal religion in that it has always been theological". When one compares the different traditions with one another, it becomes immediately apparent that the Reformed part of the Christian church has yielded a rich variety of creedal statements, far beyond the number and scope of the Catholic and Lutheran (and, lately, the Pentecostal) traditions.

This is not only evident from Leith's inclusive volume, but from the well-known collection sy EFK Möller (1903) that starts with the pre-Calvinist confessions (notably Zwingli's theses from 1523) and ends (54 statements of faith later!) with the American Congregationalist confession from 1883; the collection, Reformed witness today (1982), edited by Lukas Vischer, which includes confessional texts and statements of church unions from all continents; the collection and theological interpretation by Jan Rohls (1988) of the old Reformed confessional writings stemming from the Zurich reformation up to the Barmen declaration of $1934^{3}$; and the more recent annotated commentaries published by Neukirchener Verlag, Reformierte Bekenntnisschriften, which will include confessions from 1523 until today (also the Belhar confession).

As we celebrate the most ecumenical of the Reformed confessions, namely the Heidelberger Catechism, it is apt to ask why the creeds of the Reformed churches show such a remarkable variety and multiplicity. The answer is sought below in a discussion of the nature of Reformed theology (Willie Jonker), the spiritual power of the church to declare and interpret doctrine (John Calvin), and the character of Reformed confessions themselves (Karl Barth).

2 The text is found in G.W. Lochner (ed.), Der Berner Synodus von 1532, vol. 1, 26, published in 1984 by Neukirchener Verlag. I found the reference and translation in Busch 2003:23. The significance of this quotation will be evident from the discussions below.

3 See Rohls 1998:3-4, and 16 for reference to other collections, including H.A. Niemeyer's collection of Reformed confessions, Collectio confessionum in ecclesiis reformatis publicatarum, published in 1840 (to which Mueller also refers in his preface) and the more recent article by W. Neuser in the Handbuch der Dogmen- und Theologiegeschichte vol. 2, 165-166 (edited by C Andresen, 1980). See Möller 1903:xiii for an interesting list of older collections of Reformed confessions. 


\section{JONKER: WHAT IS THEOLOGY? ${ }^{4}$}

In an article, "What is theology?" written for a 1976 consultation of the Reformed Ecumenical Synod, South African systematic theologian, Willie Jonker (1976:3-7), ${ }^{5}$ distinguishes four models of theology. These are (i) theology as mystical knowledge of God, constituting theology as "wisdom" (Augustine and the Eastern Orthodox tradition); (ii) theology as rational knowledge about articles of faith (Aquinas and Roman Catholic scholasticism); (iii) theology as knowledge of God via revelation in Scripture (the Protestant tradition inaugurated by Luther and Calvin); and (iv) theology as knowledge of God via human experience or religiosity (Schleiermacher, Neo-Protestant- and Pentecostal theologies).

Jonker then makes a conscious choice for the Protestant model because - according to him - the Scriptures are taken as source, object and criterion of theology in a more adequate manner than in the other models or traditions. In the mystical tradition, Scripture is important up to a point, where-after mystical reflections may lead to a higher order knowledge of God beyond the revelation in Scripture. In the Catholic tradition, the doctrines and traditions of the church are seen as equally important sources of revelation when compared to Scripture, and these doctrines (and not Scripture itself) are the actual object of theological study. He, interestingly, considers the model of experiential theology the least attractive, as he views this as an anthropocentric way of speaking about God in terms of religious experience with only a relative position assigned to Scripture, thereby in fact deserting the very modus of theological language (Jonker 1976:7).

Jonker goes further and positions himself in the specific Reformed tradition within broader Protestant theology. ${ }^{6} \mathrm{He}$ draws distinctions between Luther and Calvin, and argues that the valid insights from Luther should

$4 \quad$ The following paragraphs on Jonker are extracts from a longer essay on his work published in Verbum et Ecclesia under the title: "A public theology from within the church?" See Naudé 2014.

5 Jonker (1929-2006) taught Practical Theology in Kampen (The Netherlands) from 1968-1971 and Dogmatics at the Stellenbosch theological faculty from 1971 to his retirement in 1994 . He played a major role in the church struggle from within the Dutch Reformed Church, always steering toward the Reformed roots of the church. For our current discussion, his book on Reformed confessions (including a discussion of the Heidelberg Catechism), published as Bevrydende waarheid (Liberating truth) in 1994, is of specific significance.

6 See Jonker's (1974:232-260) contribution in the Heyns \& Jonker co-publication, Op weg met die teologie. 
be maintained, but supplemented by the broader theological vision of John Calvin (Heyns \& Jonker 1974:248-252).

Jonker works in broad strokes here: In depicting the relationship between God and humans, Luther would emphasise the holiness of God and sinful nature of the human being, whereas Calvin works on the basis of our Creator God in relation to the fallen creation, including fallen human beings. Justification for Luther is being saved from sin; whereas for Calvin justification encompasses the recreation of all of reality and God's saving act from sin and all destructive powers. Luther interprets the rule of Christ via the "two kingdoms" view where the law has as primary role the revelation of sin; whereas Calvin views Christ's rule as a rule over all of reality in the one kingdom of God with the law as a guide to holiness and the transformation of society (Heyns \& Jonker 1974:251-252). This last point - obedience to the law of God as revealed in the Bible for the whole political and social order - is put by Pelikan as "the most characteristic difference between Lutheran and Calvinist views of obedience to the word and will of God" (Pelikan 1984:217).

Already in the question as to what theology actually is, lies the answer of why the Reformed tradition has given rise to a multiplicity of confessional statements: Because the revelation of God in Scripture is taken as the sole source and criterion of the Gospel truth which spans the whole of society and is proclaimed anew in and for each time.

One can thus say that the Reformed churches hold an "open" rather than a "closed" confessional tradition where the former holds a particular statement of faith to be adequate for all times and places, and the latter holds that statements of faith follow one another as a line of gospel proclamation in history, always expecting new confessions as may be required from time to time ${ }^{7}$ (Stotts 1998:xi). Leith remarks that Reformed Protestantism "has been prolific in the production of creeds" over a long period of time and emanating from wide geographical areas.

Hence the Reformed creeds exhibits a variety that is the nemesis of all those who would write the theology of the Reformed confessions (Leith 1973:127, original emphases). ${ }^{8}$

7 There are different reasons why confessions are adopted. These may vary from internal strife around specific doctrines, the needs of catechism and liturgy, statements accompanying church unification processes, or - in extreme cases - as a response to a status confessionis or situation in which it is judged that the very nature of the church and the very truth of the gospel are at stake.

8 There are indeed some distinctive Reformed doctrines in relation to (for example) Holy Communion, the third use of the law, and predestination, but "one of the hallmarks of Reformed theology is that no single creed or teaching 
Let us investigate this by a closer reading of Calvin's discussion of the spiritual power of the church to declare doctrine, and of Barth's view on the nature of the Reformed confessions in contrast to Concordist Lutheranism.

\section{CALVIN: NO NEW DOCTRINE? ${ }^{9}$}

After discussion in his Institutes of the marks and government of the church, Calvin (IV.8.1) considers the spiritual power of the church in terms of doctrine, jurisdiction (legislation) and in enacting laws. It is the first of these powers that concerns us here: the authority to deliver dogmas, and the power to interpret them.

Calvin (IV.8.2) enters into a broad discussion of the Old Testament prophets and makes clear that

whenever they are called to office, they are enjoined not to bring anything of their own, but to speak by the mouth of the Lord.

Referring to the examples of Moses, Ezekiel, and Jeremiah, Calvin (IV.8.3) reiterates that "none of the prophets opened his mouth unless preceded by the word of the Lord". Their power and authority rests solely on their being "organs of the Holy Spirit" in that the prophets were "strictly bound not to deliver anything but what they received" (Calvin IV.8.3).

The same holds for the apostles in the New Testament: Their authority rests on the fact that they do not speak "their own pleasure, but faithfully deliver the commands of him by whom they are sent" (Calvin IV.8.3). Just as Christ relies on the Father for his doctrine (John 7:16), so the apostles are sent to teach the nations whatsoever is commanded by Christ, and "not what they themselves had at random fabricated" (Calvin IV.8.8).

office has been vested with the power to state definitively what the boundaries of Reformed opinion sought to be" (Johnson 2003: 66). Read Smit 2010 for a good overview discussion on the search for a specific "Reformed" identity, and note the remark by Eberhard Busch: "Apparently it belongs to the structure of the Reformed tradition itself to question its confessional identity" (Busch 2003:20). He writes this just before he ventures to outline the specific profile of Reformed thought in relation, inter alia, to the Heidelberg Catechism (29-33).

9 Note that Calvin uses the word "doctrine" in the general sense of "teaching" and in the more specific sense of "dogma" or "confession". See the Opitz, Calvins theologische Hermeneutik with a chapter on the preaching of the Word of God as "doctrina" (1994), and also the d'Assonville's doctoral dissertation, Der Begriff "doctrina" bei Johannes Calvin - eine theologische Analyse (2000) for a detailed analysis of Calvin's use of the word "doctrina". 
The power of the church to deliver doctrine is therefore a limited power. It is not infinite, "but is subject to the word of the Lord and, as it were, included in it" (Calvin IV.8.4). The word of the Lord refers firstly to Christ as the only true manifestation of God. The Father appointed the Son as our teacher,

ordering us to seek the whole doctrine of salvation from him alone, to depend on him alone, in short, to listen only to his voice (Calvin IV.8.7).

But God was pleased to commit and consign his word to writing, and the Scriptures therefore serve as source and yardstick of all doctrine. Under guidance of the Holy Spirit, the Spirit of Christ, the Church is to remember the teachings of Christ. The supreme power that pastors of the church carry, is to boldly witness to the word of the Lord, and not to coin new doctrine or design new decrees which are mere "fictions of men" (Calvin IV.8.9). Yes,

God deprives man of the power of production of new doctrine, in order that he alone may be our master in spiritual teaching, as he alone is true, and can neither lie nor deceive (Calvin IV.8.9).

Calvin (IV.8.12), however, does not deny that the church has the power to "deliver dogmas", but then such dogmas must be judged by the word of God to see whether "the word of the Lord is faithfully preserved and maintained in purity", or whether these are doctrines "extraneous to the word of God" (Calvin IV.8.13). He fiercely denies the Roman Catholic view that the promise of the Spirit to the Church automatically implies that the church cannot err. If a Council meets and acts in contempt of the word of God by coining dogmas contrary to the word of God, the church strays from the right path and misuses her authority to demand assent to those decisions (Calvin IV.8.14). In simple terms:

... we cannot concede to the church any new doctrine; in other words, allow her to teach and oracularly deliver more than the Lord has revealed in his word (Calvin IV.8.15).

The word of the Lord is thus the source of dogma that may never state more than the word, and the word is the measure by which dogma is to be interpreted. Calvin is clear: This restriction does not mean that no new words or phrases may be designed to express the truth of the gospel. In Nicea we confess that the Son is "consubstantial" (homo-ousios) with the Father, and although this term does not appear in Scripture, it does "simply declare the genuine meaning of Scripture" (Calvin IV.8.16). 
If the measure of the word of the Lord, the only "sure law of discrimination" (IV.9.9), is applied to the Councils, not all pass the test. If measured by the authority of Scripture, the councils of Nicea, Constantinople, Ephesus I and Chalcedon are to be affirmed as "they contain nothing but the pure and genuine interpretation of Scripture" (Calvin IV.9.8). But Ephesus II and the Council of Nice are repudiated because the former confirmed the Eutychian heresy ${ }^{10}$ (Calvin IV.9.13), and the latter condoned the setting up of images in the church, opening the door for idolatry (Calvin IV.9.9). The same repudiation holds for teachings on purgatory, the priestly celibate, intercessions of saints and auricular confession as "not one syllable can be found in the Scripture" (Calvin IV.9.14) to support them.

It is clear from this exposition of Calvin's thought that Christ as attested to in Scripture is the only basis for the authority of the church to formulate doctrine. The limits set by the Scriptures in the confessions of the church are twofold: Scriptures are the source of doctrine and such doctrine is a mere interpretation of Scripture. And when the church does accept or proclaim doctrine, only Scripture acts as judge of its orthodoxy (Calvin IV.9.9).

This tendency to "relativize" dogma and put it under the constant proviso of the Word of God is exactly one of the grounds for the multiplicity of confessions in the Reformed tradition. This is confirmed and further explained in Barth's discussion of the task of dogmatics and the nature of Reformed confessions.

\section{BARTH: “... A PUZZLING AND PARADOXICAL PICTURE?"11}

In explaining the task of dogmatics, Barth takes at least three factors into account that explain the provisional nature of dogmatics and subsequently of confessions:

First, dogmatics as a science shares with all sciences the trait of always being "preliminary and limited" and merely an attempt at knowledge (Barth 1949:9). For Christian doctrine, this "attempt" is specifically related to the gospel which is "boundless, eternal and therefore inexhaustible" so that no doctrine is able to reproduce its fullness. The gospel of Jesus Christ

10 Eutyches $(380-$ c. 456$)$ was judged heretical in his view of the two natures of Christ by the Synod of Constantinople in 448, but was re-instated in 449 at Ephesus II (Calvin's reference here), and again deposed at Chalcedon in 451.

11 "Discerning the significance of the confession in the Reformed church has presented us with a puzzling and paradoxical picture." See Barth 2002:38ff. 
relates to God's own perfect work and - measured by it - our human descriptions are always imperfect (Barth 1964:18).

Second, dogmatics does not fall from heaven nor does the Christian Church exist in heaven, but amid earthly and human circumstances so that dogmatics that studies the "what" (content) of the church's proclamation always reflects knowledge "as it has been given to us today" - knowledge that is relative and liable to error (Barth 1949:11).

Third - and more directly relevant to our topic - the guidance of the confessions, the "witness of the Fathers" has to be taken seriously, but always keeping in mind that the confessions stand under Scripture and have a relative and non-binding authority. ${ }^{12}$ "Holy Scripture and the Confessions do not stand on the same level. We do not have to respect the bible and tradition with the like reverence and love, not even the tradition in its most dignified manifestations. No Confession of the Reformation or of our own day can claim the respect of the Church in the same degree that Scripture in its uniqueness deserves it" (Barth 1949:13).

The corpus of confessions within the Reformed tradition shows a marked fluidity and openness derived from its lived context-dependency, the specificity of its content, and its provisional authority.

The context-orientation refers to the fact that if the church lives under the living word of God and is always being reformed according to the Word of God, there will always yet again arise occasions where the proclamation of the church is directed at a new situation requiring the Word of God to be spoken differently to be a word for that place and that time. This is why Barth defines a Reformed creed as a statement publicly formulated by a Christian community "within a geographically limited area", thereby providing one reason why a general or universal Reformed creed is simply not a good idea:

I can believe with the most distant, with the ecumenical company; I can confess my faith only with my neighbours, that is with those known to me as fellow believers (Barth 1962:125) ${ }^{13}$.

Reformed confessions "bear the marks of the occasional, of relatedness to a specific time and situation, of the unique" (Barth 2002:20).

12 See Georg Plasger's authoritative work, Die relative Autorität des Bekenntnisses bei Karl Barth (2000) for an interpretation of Barth's understanding of confessions.

13 See Naudé 2010:95ff for a discussion of Barth's definition of a Reformed confession as applied to the Belhar confession. 
The content-specificity is closely tied to the spatial limits of the creeds: A creed does not cover the whole of Scripture; it is not a general theological treatise, but addresses a specific aspect of the will of God. It refutes a specific lie or half-truth; it offers something definite in the name of God. To attempt writing a confession so that "as many as possible can rally under the banner of a very general 'yes' can happen only at the price of the 'yes'" (Barth 1962:129).

In his reflection on the Heidelberger Catechism (originally from 1948), Barth (1964:22) states clearly:

Good (i.e. right) Christian doctrine does not take place in the vacuum of solitary thinking; it chooses its place in the fellowship of saints, in connection with the living, thinking, knowing of the whole Christian church.

He judges the positive impact of the $\mathrm{HC}$ from the fact that - unlike some other confessional writings - "it grew out of the immediate necessities of the life of a church" (Barth 1964:22; emphasis original).

In his contribution to Martin Niemoller's Festschrift, Barth (1952:10; my emphasis) reflects as follows on the Barmen declaration:
Barmen war darum (im Unterschied zu manchen kirchlichen Schriftstücke, die so heissen) ein echtes, ein kirchliches Glaubens- bekenntnis, weil seine Sätze nich im leeren Raum einer bloss theologischen Diskussion, sondern in einem konkreten Akt und Bezug des Bekennens einer christlichen Gemeinde, im Feuer eines handgreiflich konkreten Gegensatzes zu ihrem Zeugnis, als Theorie einer bestimmten praktisch notwendigen Verantwortung ausgesprochen wurden.

He goes so far as to say that the power of the Barmen declaration stands or falls with the presupposition that it was confessed and spoken in the church, as the church, and for the church at that specific place and in that specific context (Barth 1952:12).

The provisional nature of the confessions is at a more fundamental level to be derived from their position under Scripture. A creed is always formulated “... until further action", because the on-going revelation of God in Jesus Christ as attested to in the Scriptures can never be fully and finally captured by our creeds, and the church always stands under guidance of the Spirit of Jesus Christ who allows and commands what should be confessed (Barth 1961:86). No matter how widespread a Reformed confession is acknowledged, it is always intended as "merely provisional, improvable and replaceable offerings", and always open to be corrected 
from Scripture (Barth 2002:24). ${ }^{14}$ The significance of the Reformed confessions, writes Barth, "consists in its essential nonsignificance, its obvious relativity, humanity, multiplicity, mutability, and transitoriness" (Barth 2002:38).

This is the basis for Barth's polemic with the significance of the confessions within the Lutheran church. He acknowledges that a "reasonable Lutheranism" could stand its ground in the Heidelberger Catechism (Barth 1964:25) as the latter expresses the great truth, commonly recognised in the Reformation. But he returns to The Book of Concord (1580) $)^{15}$ - and specifically the Formula of Concord's view on the Augsburg Confession - which leaves for him an ambiguous impression with regard to the two important matters:

First, the Augustana is the one, final symbol of the Lutheran church, confessing the ancient faith (like Nicea) and serving as guideline for the interpretation of all other expressions of faith, not only for its own time but ad omnem posteritatem (Barth 1962: 115). This creates a closed hermeneutical frame devoid of the provisional nature of confessions in the Reformed tradition. ${ }^{16}$

Second, and for Barth even more unacceptable, is the fact that although Scripture is confessed as "eternal truth" and as "basis" of all truth standing in "brilliant distinction" to all other writings - the Augustana is brought into remarkable proximity to the Holy Scriptures, and is presented in some formulations as having the similar normativity to judge other writings than is accorded to the Scriptures. This places the Augsburg Confession beyond the questioning and criticism of Scripture, because "the dignity of Scripture" (Barth 2002:5) has been transferred to it, rendering it no longer a mutable, but rather an "immutable entity" (Barth 2002:6).

The binding obligation put upon Lutherans by this authoritative confession, brings advantages: Against the Catholic church, Lutherans

14 See the reference to examples like Zwingli's Sixty Seven theses, the Bern consensus, and the Duisberg General Synod of 1610 (Barth 2002: 24-25).

15 The Book of Concord includes, inter alia, the Augsburg Confession (1530), the Apology of the Augsburg Confession (1531), Luther's Smalcaldic Articles (1537); Luther's Small and Large Catechism (1529), and the Formula of Concord (1577). See Leith 1973: $61 \mathrm{ff}$ for introduction and texts.

16 Jan Rohls (1998:9) refers to the interesting impulse amongst Reformed churches - responding to Concordistic Lutheranism - to also develop a standard set of confessions that could serve a unitary norm for all other statements of faith. A prime examples of such a (failed) project, is the unionistic collection, Harmonia confessionum fide, orthodoxarum et reformatarum ecclesiarum, produced by Jean Salvard and published in Geneva in 1581. 
now have their own authoritative understanding of the Bible (i.e. their own authoritative tradition acting as unitary norm of doctrine); and against the Reformed churches that live in the uncertainty of always confessing under the judgment of Scripture, Lutherans have the certainty and dignity of a viewpoint promulgated as law.

But, argues Barth, these advantages could never be acceptable in the Reformed churches: Tradition - even the most highly venerated confessions - can never carry the same authority or dignity as the Scriptures.

The Reformed confessions are and desire to be nothing other than mere human confessional acts, over against which the revelation of God in Scripture also stands as a given" (Barth 2002:20, emphasis original).

Reformed confessions - which should never be called "symbols"17 are indeed "sincere expositions of faith" (Calvin). They should be viewed with reverence and thankfulness for those who confessed before us, but there must be freedom in the communion of saints via a re-interpretation (and not mere repetition) of past confessions.

Not to allow and require such freedom would mean that we in the church had returned to a kind of tradition which stands with equal honour alongside Holy Scripture (Barth 1964:21-22).

The confessions should however also not be viewed as permanent laws for interpreting Scripture (like a frozen river on which one could walk), because they are by their very nature open for examination and discussion, requiring time to prove themselves (like a freely flowing river in which one can only swim) (Barth 2002:20, 27). "Gottes Wort und Luther's Lehr vergehen nun und nimmermehr" could, says Barth, "never be uttered by a Calvinist". Just as impossible would be to talk about "the Word of God and the Augsburg Confession" in one line (Barth 2002:21).

The so-called perceived "deficiencies" brought about by this understanding of the Reformed confessions must all be brought back to one fundamental point: The church is called to witness to the gospel of Jesus Christ

17 Barth, in his analysis of the HC, even avoid speaking about the Heidelberg orthodoxy, as that could be interpreted as an "unmoveable and unchangeable" doctrinal view (1964:21). He also stands firm against any attempt toward confessionalism, "... one of the most questionable things which is happening today in German theology and in the German church" (1964:22). 
not as the truth in our mouth but as the truth in God's mouth ... The witness (as person) stutters, and the witness (as content) is confused, but the Word of God will stand for ever (Isa. 40:8) (Barth 2002:39).

In short:

Ultimately, the Reformed principle of Scripture $^{18}$ forces the Reformed confession against the wall and renders it so fragmented, so desecrated, so human and temporal, so minimally binding. 'Woe is me, I am lost', it says, and as by a devouring fire, the truth of Scripture that is confessed, attacks the truth of the confession, puts it in question, destroys it to the extent that it does not glow with the same fire that consumes it. Reformed confession is confession of the truth of Scripture; as long as and to the extent that it is this, it has not ceased to exist (Barth 2002:40).

\section{CLOSING REMARKS}

In this paper it was noted that a multiplicity of confessional statements is particular to the Reformed tradition. Examples of such collections from the Reformation times up to the present were cited at the beginning.

It was then argued that the reason for this creedal plurality should be sought in the very understanding of theology as reflection on God's revelation in Scipture (Willie Jonker); in the limited spiritual power of the church to produce and interpret new doctrine (John Calvin), and in the radical proviso of confessions that - though held in high reverence always stand under the ultimate authority of Scripture and are therefore treated with marked freedom in the communion of saints (Karl Barth).

Because the church lives in the power of the Spirit and the Word - as specifically interpreted in Reformed circles - there will always be further confessions. These confessions are gifts of insight into the gospel truth, given at a specific time and in a specific place, as both positive witnesses to the revelation of God and pointing out possible heresies that might in new ways dilute the apostolic faith.

There will be new confessions. Until further action ...

18 There is no room in this paper to go into the complex dogmatic and hermeneutical questions related to the so-called "Scriptural principle". For an enlightening discussion by Michael Welker, read "Sola Scriptura? The authority of the Bible in pluralistic environments" (Welker 2002). 


\section{BIBLIOGRAPHY}

BARTH, K.

1949. Dogmatics in outline. London: SCM Press.

1952. Barmen. In: J. Beckmann \& H. Mochalski (eds.): Bekennende Kirche. Martin Niemoeller zum 60. Geburtstag, (Muenchen: Chr Kaiser Verlag), pp.9-17.

1961. Church dogmatics, III/4: The doctrine of creation. Edinburgh: T\&T Clark.

1962. The desirability and possibility of a universal Reformed creed. In Theology and church: Shorter writings, 1920-1928. London: SCM Press.

1964. Learning Jesus Christ through the Heidelberg Catechism. Grand Rapids: Eerdmans.

2002. The theology of the Reformed confessions 1923. Louisville: Westminster John Knox.

Busch, E.

2003. Reformed strength in denominational weakness. In: W.M. Alston Jr and M. Welker (eds.). Reformed theology. Identity and Ecumenicity, (Grand Rapids: Eerdmans), pp.20-33.

CALVIN, J.

1975. Institutes of the Christian religion. Grand Rapids: Eerdmans.

D'ASSONVILLE, V.E.

2000. Der Begriff "doctrina" bei Johannes Calvin - eine theologische Analyse. Münster-Hamburg-London: Lit Verlag.

HeYNS, J.A. \& JONKER, W.D.

1974. Op weg met die teologie. Pretoria: NG Kerkboekhandel.

JoHnson, W.S.

2003. Theology and the church's mission: Catholic, Orthodox, Evangelical, and Reformed. In: W.M. Alston Jr \& M. Welker (eds.). Reformed theology. Identity and Ecumenicity. (Grand Rapids: Eerdmans), pp.65-81.

JONKER, W.D.

1976. What is theology? In: P.C. Schrotenboer (ed.): Church and theology in the contemporary world, (Grand Rapids: Michigan), pp.3-15.

1994. Bevrydende waarheid. Wellington: Hugenote Uitgewers.

LEITH, J.

1973. Creeds of the churches. A reader in Christian doctrine from the Bible to the present. Oxford: Basil Blackwell.

MulleR, E.F.K. (HRSG.)

1903. Die Bekenntnisschriften der reformierten Kirche. Leipzig: Deichert.

NAUdÉ, P.J.

2010. Neither calendar nor clock. Perspectives on the Belhar confession. Grand Rapids: Eerdmans. 
2014. A 'public theology' from within the church? A reflection on aspects of the theology of W.D. Jonker (1929-2006). Verbum et Ecclesia 35(1), 8 pages. Doi:10.4102/ve.v35i1.1136. .

Neuser, W.

1980. Dogma und Bekenntnis in der Reformation. In: C. Andresen (ed.) Handbuch der Dogmen- und Theologiegeschichte vol.2, (Stuttgart:Vandenhoeck \& Ruprecht), pp.165-166.

OpITZ, P.

1994. Calvins theologische Hermeneutik. Neukirchener Verlag: Neukirchen.

Pelikan, J.

1984. Reformation of church and dogma (1300-1700). The Christian tradition, vol. 4. Chicago: University of Chicago Press.

Plasger, G.

2000. Die relative Autorität des Bekenntnisses bei Karl Barth. Neukirchen: Neukirchener Verlag.

RoHLS, J.

1998. Reformed confessions. Theology from Zurich to Barmen. Louisville: Westminster John Knox.

SMIT, D.J.

2010. Trends and directions in Reformed theology. The Expository Times 122(7):1-14.

STOTTS, J.L.

1998. Introduction: Confessing after Barmen. In: J. Rohls (ed.) Reformed confessions. Theology from Zurich to Barmen, (Louisville: Westminster John Knox), pp. xi-xxiv.

VISCHER, L. (ED.)

1982. Reformed witness today. A collection of confessions and statements of faith issued by Reformed churches. Bern: Evangelische Arbeitstelle.

WELKER, M.

2002. Sola Scriptura? The authority of the bible in pluralistic environments. In: B. Strawn (ed.). A God so near. Festschrift for Patrick D Miller, (Winona Lake: Eisenbrowns), pp.375-391.

Keywords

Reformed tradition

Reformed confessions

Willie Jonker

John Calvin

Karl Barth
Trefwoorde

Gereformeerde tradisie

Gereformeerde belydenisse

Willie Jonker

Johannes Calvyn

Karl Barth 